\title{
DEVELOPMENT OF NOVEL ENVIRONMENTALLY SAFE AND HIGHLY EFFICIENT FIRE-EXTINGUISHING POWDERS BASED ON LOCAL MINERAL RAW MATERIALS
}

\author{
LALI GURCHUMELIA ${ }^{1}$, MURMAN TSARAKHOV ${ }^{1}$, SALOME TKEMALADZE ${ }^{2}$, \\ GEORGE BEZARASHVILI ${ }^{2}$ \& LASHA TKEMALADZE ${ }^{3}$ \\ ${ }^{1}$ TSU Rafael Agladze Institute of Inorganic Chemistry and Electrochemistry, Georgia \\ ${ }^{2}$ Ivane Javakhishvili Tbilisi State University, Georgia \\ ${ }^{3} \mathrm{G}$. Tsulukidze Mining Institute, Georgia
}

\begin{abstract}
The aim of the presented investigation is the development of the novel halogen free, environmentally safe and highly efficient universal (working on several classes of fires) fire-extinguishing powders on the basis of local mineral raw materials. The technology for production of these powders differs from the convenient production technology, is much simpler and significantly cheaper. Powders will be produced by mechanical milling of local mineral raw materials, which do not require modification with expensive halogen-containing hydrofobizing additives, making the extinguishing materials far cheaper than imported analogues. Optimal dispersity of powders was selected to provide the minimal caking capacity, a homogeneous action of combustion products on the flame and a heterogeneous inhibition of combustion process. The evaluation of powder efficiency was carried out considering the both effects. For a comprehensive evaluation of the extinguishing effect two special characteristics were selected: the reciprocal value of extinguishing "surface" concentration ("surface" concentration means a total surface area of powder particles in a unit volume) and the coefficient of recombination of atomic oxygen on the surface of solid particles (measured using Electro Paramagnetic Resonance (EPR) methods). In order to evaluate the fire-extinguishing ability of powders, the "polygon testing" methods are used, which consider extinguishing of different class of standard fires with the help of standard fire-extinguishing constructions. Experimental data confirm that the developed fire-extinguishing powders are characterized with high performance characteristics, as well as high fire-extinguishing capacity. At the same time, it should be noted, that the efficiency of the obtained powders is practically the same as of standard imported powders, but do not contain any halogens, is environmentally safe and 1.5-2 times cheaper than the imported analogues.

Keywords: halogen free, environmentally safe, highly efficient, zeolite-containing, fire-extinguishing powders.
\end{abstract}

\section{INTRODUCTION}

Fires are an unsolved acute problem of world civilization. Within the recent years, the amount of fires increased progressively, while the damage done is comparable to the consequences of terrorist activities. Rapid growth of the damage caused by fires is embarrassing and comprises tens of billions of dollars annually. Injury and poisoning of people is often caused not only by combustion products, but also by toxicity of the utilized fire-extinguishing agents. The existing statistics shows that the currently used conventional fire-extinguishing substances $\left(\mathrm{CO}_{2}\right.$, water and foam), are comparatively expensive, neither universal, not environmentally safe and have a quite low efficiency. Therefore, the problem of inhibition of burning processes, in the zone of inflammation and elimination of toxic materials emissions remains to be acute. Nowadays, fire-extinguishing powders are considered to be the most efficient fire-extinguishing agents due to their universality and high efficiency [1]-[3]. 
As is known, the commonly produced and used fire-extinguishing powders are the finely dispersed mineral salts with different additives, which improve the performance properties of salts, in particular, the unwanted tendency for consolidation and caking. All they are rather complicated multicomponent heterogeneous systems, and their fire-extinguishing capacity (as well as other performance properties) is mainly determined by the chemical composition. In order to improve performance properties (mainly, to decrease the caking capacity) water absorbing additives are used for hydrophobization of powders. Halogen containing organic hydrophobizers are mainly used as additives. Thus, most of them are containing halogen and do not satisfy the contemporary demands for effective, non-toxic, environmentally safe and universal fire-distinguishing agents. It is unambiguously stated that when halogen gets into atmosphere it causes the disturbance of ozone layer [3], [4]. Therefore, development of halogen free, nontoxic, environmentally safe fire-extinguishing powders is currently a very important problem.

This paper examines the methods of development of technology for production of novel, halogen free, environmentally safe, highly efficient and universal fire-extinguishing powders on the basis of local mineral raw materials, which can be used for extinguishing of all classes of fires in underground and aboveground locations.

The technology for production of these powders is simple and significantly differs from the conventional technologies. Powders will be made by mechanical milling of local mineral raw materials and do not require the modification with expensive halogen containing hydrofobizing additives, providing low-cost production of fire-extinguishing powders in comparison with imported analogues.

Raw materials - zeolite, clay shale and perlite - were selected due to their high-performance properties and ability to suppress the combustion and burning processes, which can be predicted using the results of chemical and thermal gravimetric analysis. Most of utilized materials are silicate origin and containing alkali and alkaline-earth carbonates, bicarbonates, silicates also iron, aluminium, alkali metal hydroxides and crystallization water. Intensive heating causes decomposition of the utilized materials and emission incombustible gases, water steam and metal oxides. The released incombustible gases and water steam in flame zone are functioning as phlegmatizer and in surface zone are causing the formation of swelled layer. The latter, protective films of metal oxides, swelled and coked layer cause a strong "fire-limiting" effect. This indicates the fact that these materials can reveal the properties similar to highly effective homogeneous inhibitors [5].

The extinguishing powders must not only effectively limit and suppress the fire, but they also should maintain their performance properties unchanged for the prescribed period because even a slight worsening of properties can significantly decrease the powder effectiveness. The most important performance characteristics are the following: powder dispersity, apparent density, powder compaction, tendency to consolidation and caking, tendency to humidity, powder fluidity and storage duration. The most undesirable performance property is the tendency of consolidation and caking, which hinders and conclusively cancels the fire-extinguishing ability of the powder. The main factors, which usually cause consolidation and caking, are high humidity and temperature of the surrounding medium. Powders absorb moisture from air - it can be said that solid particles are dissolved in condensed water, and a saturated solution of the solid phase is formed. By further dissolving solution becomes supersaturated and crystallization from the solid phase takes place at the contact surfaces of the supersaturated and saturated parts. Formation of phase contact surfaces is possible only in the conditions of new coagulation. An average strength of elementary contacts of individual particles depends on the strength of powder structure 


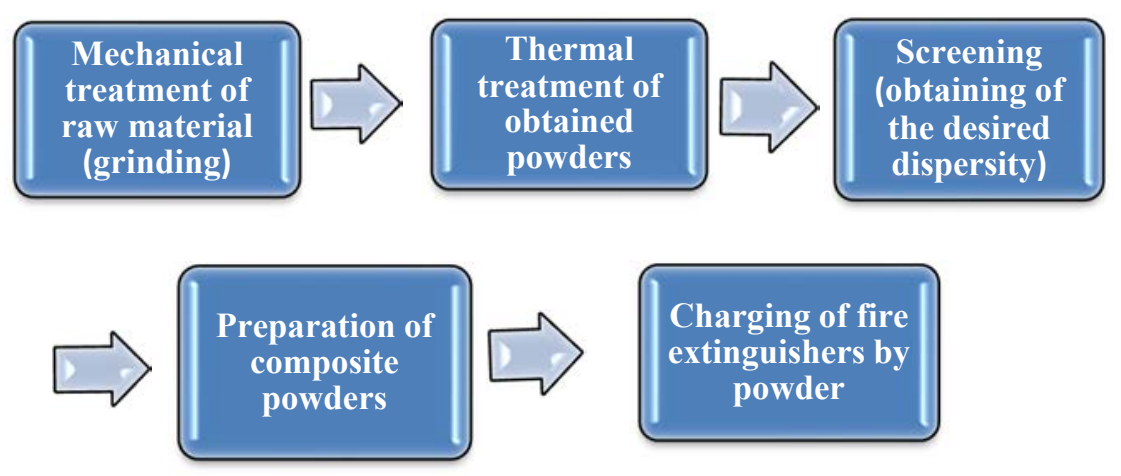

Figure 1: Technological process for production of fire-extinguishing powders.

(packing, consolidation and caking), which, in its turn, depends on dispersity, settling and compaction rate of particles. The performed studies showed that the tendency to consolidation and caking decreases with decreasing of dispersity, and when powder dispersity is within $200-250 \mu \mathrm{m}$ the caking capacity drops to zero [6], [7].

\section{EXPERIMENTAL PROCEDURE}

The technology for production of powders is simple and differs from the conventional production (Fig. 1). According to this technology, fire-extinguishing powders are prepared using only mechanical treatment (grinding, screening up to $250 \mu \mathrm{m}$ dispersity, drying at $700-100^{\circ} \mathrm{C}$ ) and mixing of raw materials. It does not require any additional chemical processing and modification using expensive halogen containing hydrophobizing additives. Due to the developed technology, production processes are simplified and costs are reduced.

\subsection{Performance properties}

In order to study performance properties of powders laboratory standard methods [8], [9], are used:

- powder dispersity, $x(\%)$ - granulometric composition, mass concentration of powder remains left on the sieve

$$
x=\frac{m_{1}}{m} \cdot 100,
$$

where: $m_{1}$ - mass of powder remains left on the sieve, $\mathrm{kg}$;

$m$ - total mass of powder, $\mathrm{kg}$.

- powder fluidity, $Q(\mathrm{~kg} / \mathrm{s})$ - powder mass consumption in time necessary for its flow from tested fire extinguisher

$$
Q=\frac{m-m_{\tau}}{\tau}
$$

where: $m$ - mass of extinguisher before testing, $\mathrm{kg}$. 
$m_{\tau}$ - mass of extinguisher after testing, $\mathrm{kg}$;

$\tau$ - testing time, sec;

- moisture content and tendency to humidity, $W(\%)$ - the ratio of moist absorbed by the powder to powder mass

$$
W=\frac{m_{1}-m}{m} \cdot 100,
$$

where: $m_{1}$ - mass of powder remains after moistening, $\mathrm{kg}$;

$m$ - total mass of powder, $\mathrm{kg}$;

- coefficient of compaction, $\mathrm{K}$ - the relation of height of bulk powder before and after compaction

$$
K=\frac{H_{1}}{H_{2}},
$$

where: $H_{1}$ - height of bulk powder before compaction, $\mathrm{cm}$;

$\mathrm{H}_{2}$ - height of bulk powder after compaction, $\mathrm{cm}$;

- tendency to consolidation and caking, $C(\%)$ - caked mass ratio to total powder mass:

where: $m_{\mathrm{c}}$ - mass of formed cakes, $\mathrm{kg}$;

$$
C=\frac{m_{c}}{m}
$$

$m$ - total powder mass, $\mathrm{kg}$;

- apparent density, $\rho\left(\mathrm{kg}^{3} / \mathrm{m}\right)$. The method to define apparent density of packed or unpacked powders is based on measurement of the ratio of volumes of free and pressed powder by vibration.

- apparent density of unpacked powder $\rho_{1}$

where: $m$ - mass of powder $(\mathrm{kg})$,

$$
\rho_{1}=\left(m / V_{1}\right) \cdot 100
$$

$V_{1}$ - volume of powder after $(180 \pm 5)$ second delay $\left(\mathrm{m}^{3}\right)$.

- apparent density of packed powder $\rho_{2}$

$$
\rho_{2}=\left(m / V_{2}\right) \cdot 100
$$

where: $V_{2}$ - volume of powder after compacting $\left(\mathrm{m}^{3}\right)$.

Storage duration - the duration of powder storage in the conditions, given in regulations, during of which the powder performance properties are within the permitted range.

Experimental results of performance factors of raw materials and composite powders are given in Table 1. Test results show, that zeolites are characterized with low tendency to consolidation and caking but high capacity of moisture absorption, which considerably decreases at admixture of clay shales and perlites. Thus, zeolite-containing composite powders are characterized both with low capacity of moisture absorption and caking ability. Thus, composite powders (zeolites, perlites and clay-shales) are characterized with higher 
Table 1: Performance properties of powder.

\begin{tabular}{|c|c|c|c|c|c|c|c|}
\hline \multirow[b]{2}{*}{$a$} & \multirow{2}{*}{ 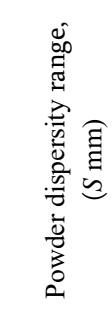 } & \multicolumn{2}{|c|}{ Apparent density } & \multirow{2}{*}{ 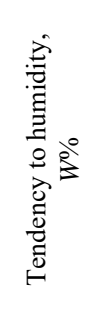 } & \multirow[b]{2}{*}{ 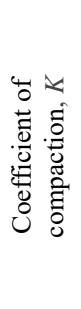 } & \multirow{2}{*}{ 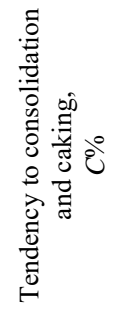 } & \multirow{2}{*}{ 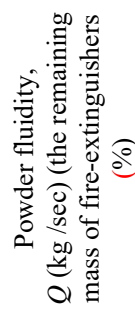 } \\
\hline & & $\begin{array}{c}\text { unpacked } \\
\text { powder, } \\
\rho_{1}\left(\mathrm{~kg} / \mathrm{m}^{3}\right)\end{array}$ & $\begin{array}{c}\text { packed } \\
\text { powder, } \\
\rho_{2}\left(\mathrm{~kg} / \mathrm{m}^{3}\right)\end{array}$ & & & & \\
\hline Clay shale & $\begin{array}{l}\# 0.1 \\
\# 0.1-0.2 \\
\# 0.2-0.3\end{array}$ & $\begin{array}{l}940 \\
870 \\
830\end{array}$ & $\begin{array}{l}1800 \\
1400 \\
1200\end{array}$ & $\begin{array}{l}1.8 \\
1.2 \\
0.8\end{array}$ & $\begin{array}{l}2.0 \\
1.72 \\
1.44\end{array}$ & $\begin{array}{l}50 \\
7.5 \\
2.0\end{array}$ & $\begin{array}{l}- \\
0.95(8.5) \\
0.9(8.1)\end{array}$ \\
\hline Zeolite & $\begin{array}{l}\# 0.1 \\
\# 0.1-0.2 \\
\# 0.2-0.3\end{array}$ & $\begin{array}{l}880 \\
840 \\
750\end{array}$ & $\begin{array}{l}1500 \\
1200 \\
1100\end{array}$ & $\begin{array}{l}5.5 . \\
4.6 \\
2.5\end{array}$ & $\begin{array}{l}1.5 \\
1.35 \\
1.22\end{array}$ & $\begin{array}{l}20 \\
0.6 \\
0\end{array}$ & $\begin{array}{l}- \\
0.86(6.3) \\
0.8(6.1)\end{array}$ \\
\hline Perlite & $\begin{array}{l}\# 0.1 \\
\# 0.1-0.2 \\
\# 0.2-0.3\end{array}$ & $\begin{array}{l}720 \\
700 \\
650\end{array}$ & $\begin{array}{c}1100 \\
1000 \\
950\end{array}$ & $\begin{array}{l}0.2 \\
0.15 \\
0.1\end{array}$ & $\begin{array}{l}1.25 \\
1.11 \\
0.85\end{array}$ & $\begin{array}{l}15 \\
0.1 \\
0\end{array}$ & $\begin{array}{l}- \\
0.75(5.9) \\
0.7(5.8)\end{array}$ \\
\hline $\begin{array}{l}\text { Zeolite + } \\
\text { Clay shale } \\
+ \text { Perlite }\end{array}$ & $\# 0.2-0.3$ & 720 & 1060 & 1.2 & 1.12 & 0.02 & $0.8(6.3)$ \\
\hline $\begin{array}{l}\text { Zeolite + } \\
\text { Clay shale } \\
+ \text { Perlite + } \\
\text { Barytes - } \\
\text { calcite }\end{array}$ & $\# 0.2-0.3$ & 750 & 1100 & 1.25 & 1.16 & 0.03 & $0.85(6.5)$ \\
\hline $\begin{array}{l}\text { Standard } \\
\text { powder }\end{array}$ & $\# 0.1-0.2$ & 750 & 1100 & 1.1 & 1.13 & 0.01 & $0.85(6.2)$ \\
\hline
\end{tabular}

performance properties than zeolites, perlites and clay shales utilized separately, and it are not worse than performance properties of the standard powders of common production. All this indicates that zeolites in composite powders can act as efficient hydrophobizing agents. Therefore, we can surmise that adding of raw materials (barites-calcites), which are hygroscopic, but characterized by high inhibiting properties, to zeolite containing composite powders will not cause significant changes of performance properties, but will considerably increase fire-extinguishing capacity.

It also should be mentioned that performance properties of powder depends on their dispersity. High dispersive powders are characterized with lower performance properties, which considerable increases with decreases dispersity.

\subsection{Fire extinguishing ability}

For a rigorous estimation of fire-extinguishing ability of powders both effects heterogeneous inhibition and homogeneous effect on flame of burning products - are taken into consideration. Heterogeneous inhibition implies heterogeneous recombination of active centers (atomic oxygen and hydrogen), on the surface of solid particles of the powder. 
Oxygen atom is one of the leading active centers of burning reactions. Therefore, the coefficient of atomic oxygen recombination - $\gamma_{0}$ was selected as one of the main characteristics of powder fire-extinguishing ability. At the same time, it should be mentioned that by heterogeneous mechanism powder fire-extinguishing capacity is estimated not by mass consumption of powder in volume unit $(G)$, but by the total surface area of powder particles of the unit volume, or by "surface" concentration $\left(C_{n} \cdot S\right)$, which can be determined by multiplication of mass concentration $\left(C_{n}\right)$ on powder specific surface area $(S)$.

So, for the complex evaluation of extinguishing effect the following special characteristics were selected:

- Reciprocal value of extinguish "surface" concentration- $1 / C_{n} \cdot S$;

- Coefficient of atomic oxygen recombination- $\gamma_{0}$.

Using Electro Paramagnetic Resonance (EPR) methods, we determined the coefficient of recombination of atomic oxygen on the surface of solid particles of the zeolites, perlites and clay shales, which ranged between $\gamma_{0}=2.6 \cdot 10^{-6} \div 6.5 \cdot 10^{-3}$. The comparison of the received results with the published data [10], showed, that the studied materials according to this parameter are considerably better than quartz and sulfates $\left(\gamma_{0} \sim 10^{-4}\right)$. On the other hand, $\gamma_{0}$ values are close to the coefficients of heterogeneous recombination of oxygen atoms on the surfaces of carbonates and chlorides $\left(\gamma_{0} \sim 10^{-3}\right)$. This shows that clay shale, zeolite and perlite can be successfully used for production of highly effective fire-extinguishing powders.

In order to determine fire-extinguishing ability the polygon testing methods are usually used, which consider extinguishing of different class standard fires with help of fire- extinguishing constructions and enable to determine: minimum quantity of powder which is consumed for fire-extinguishing, or minimum required consumption per unit area $(G)$; minimum mass concentration $\left(C_{n}\right)$ and time of fire- extinguishing $(\tau)$.

We determined fire-extinguishing ability of powders for the A (wood) and B (oil) class standard fires.

Experimental results of fire-extinguishing ability are given in Table 2. Experimental data shows, that clay shales are characterized with lower fire-extinguishing ability $\left(G-4.2 \mathrm{~kg} / \mathrm{m}^{2}\right)$, but 1.5-2 times higher coefficients of heterogeneous recombination of oxygen atoms $-\gamma_{0}$ $\left.6.510^{-3}\right)$ compared to zeolites $\left(G-2.6 \mathrm{~kg} / \mathrm{m}^{2}, \gamma_{0}-2.710^{-3}\right)$ and perlites $\left(G-2.2 \mathrm{~kg} / \mathrm{m}^{2}, \gamma_{0}-2.6\right.$ $10^{-3}$ ). While, when clay shales are added to zeolites and perlites, the heterogeneous effect of composite powders increases considerably.

\section{RESULTS AND DISCUSSION}

On the basis of the experimental results of performance factors of raw materials it can be stated, that zeolite in composite powders play the role of efficient hydrophobizing agents. Thus, zeolite-containing composite powders are characterized with higher performance properties and donot require the addition of any expensive halogen containing hydrophobizing additives. It simplifies the technological process of production and decreases the appropriate costs.

At the same time, we can assume that adding of various raw materials (ammophos, dolomites, diatomites, calcites, etc.), which are hygroscopic, but characterized by high inhibition properties, to zeolite containing composite powders will not cause significant changes of performance characteristics, but will considerably increase their fire-extinguishing capacity. It allows to create a wide range of zeolite-containing fire-extinguishing powders on the basis of local mineral raw materials.

The analysis of experimental data shows, that the effectiveness of powder depends on their inhibition properties and on their performance characteristics as well. Therefore, for the 
Table 2: Fire-extinguishing ability.

\begin{tabular}{|c|c|c|c|c|c|c|c|}
\hline 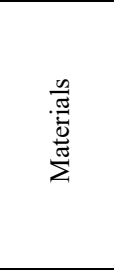 & 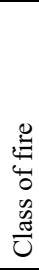 & 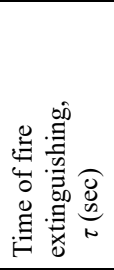 & 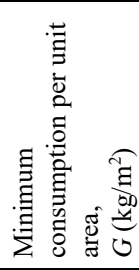 & 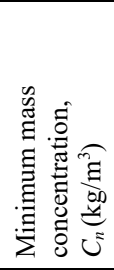 & 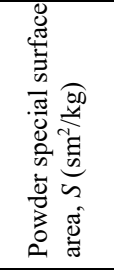 & $\begin{array}{l}\infty \\
\dot{y} \\
i\end{array}$ & 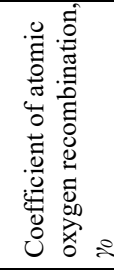 \\
\hline \multirow{2}{*}{$\begin{array}{l}\text { Clay } \\
\text { shale }\end{array}$} & $\mathrm{A}$ & 18 & 4.1 & 8.2 & \multirow{2}{*}{$4.5 \cdot 10^{6}$} & \multirow{2}{*}{$0.027 \cdot 10^{-6}$} & \multirow{2}{*}{$6.5 \cdot 10^{-3}$} \\
\hline & B & 12 & & 7 & & & \\
\hline \multirow{2}{*}{ Zeolite } & A & 15 & 2.6 & 5.2 & \multirow{2}{*}{$4.28 \cdot 10^{6}$} & \multirow{2}{*}{$0.045 \cdot 10^{-6}$} & \multirow{2}{*}{$2.7 \cdot 10^{-3}$} \\
\hline & B & 8 & & 4.8 & & & \\
\hline Perlite & $\frac{\mathrm{A}}{\mathrm{B}}$ & $\frac{12}{8}$ & $\frac{2.2}{20}$ & $\frac{4.4}{40}$ & $1.09 \cdot 10^{6}$ & $0.20 \cdot 10^{-6}$ & $2.6 \cdot 10^{-3}$ \\
\hline \multirow{2}{*}{$\begin{array}{l}\text { Zeolite + } \\
\text { Clay } \\
\text { shale + } \\
\text { Perlite } \\
\end{array}$} & A & 10 & 1.8 & 3.6 & \multirow[b]{2}{*}{$1.9 \cdot 10^{6}$} & \multirow[b]{2}{*}{$0.146 \cdot 10^{-6}$} & \multirow[b]{2}{*}{$3.3 \cdot 10^{-3}$} \\
\hline & B & 7 & & 2.0 & & & \\
\hline \multirow{2}{*}{$\begin{array}{l}\text { Zeolite }+ \\
\text { Clay } \\
\text { shale + } \\
\text { Perlite }+ \\
\text { Barytes - } \\
\text { calcite }\end{array}$} & A & 8 & 1.4 & 2.8 & \multirow{2}{*}{$3.9 \cdot 10^{6}$} & \multirow{2}{*}{$0.1 \cdot 10^{-6}$} & \multirow{2}{*}{$2.6 \cdot 10^{-3}$} \\
\hline & B & 6 & & 1.6 & & & \\
\hline \multirow{2}{*}{$\begin{array}{l}\text { Standard } \\
\text { powder }\end{array}$} & A & 7 & 1.6 & 2.5 & \multirow{2}{*}{$4.1 \cdot 10^{6}$} & \multirow{2}{*}{$0.1 \cdot 10^{-6}$} & \multirow{2}{*}{$2.5 \cdot 10^{-3}$} \\
\hline & $\mathrm{B}$ & 6 & & 1.3 & & & \\
\hline
\end{tabular}

increase of efficiency of powder, optimal dispersity (up to $250 \mu \mathrm{m}$ ) was selected in such way, that caking capacity be minimal, powder feed must be convenient (high-disperse powder direct feeding into ignition place creates many problems), performance properties to be satisfactory and a homogeneous action of combustion products on the flame as well as a heterogeneous inhibition of combustion process must take place.

Homogenous effect means heating, evaporation and destruction of powder particles when emission of incombustible gases takes place and metal oxides are provide the burning processes inhibition. It is known, that if powder particles dimensions exceed $70 \mu \mathrm{m}$, there is usually no time to heat them to ignition temperatures and, therefore, homogeneous mechanism of extinguishing is less effective, while heterogeneous mechanism has a leading role, which means heterogeneous removal of reaction active centers (atoms and radicals) on the surface of solid particles of the powder.

Considering both (homogenous as well as heterogenous) effects for a rigorous estimation of fire-extinguishing ability of composite fire-extinguishing powders the following characteristics were selected:

- Reciprocal value of extinguish "surface" concentrate $-1 / C_{n} \cdot S$;

- Coefficient of atomic oxygen recombination $\left(\gamma_{0}\right)$.

The study of relationship between these coefficients enables to characterize extinguishing mechanisms.

The analysis of experimental data shows that there is a symbatic relation between the fire-extinguishing capacity $\left(1 / C_{n} \cdot S\right)$ of the received powders and the recombination coefficient of atomic oxygen $\left(\gamma_{0}\right)$ (Fig. 2), which can be expressed with the following equation: $1 / C_{n} S=1262.8 \gamma_{0}$. 


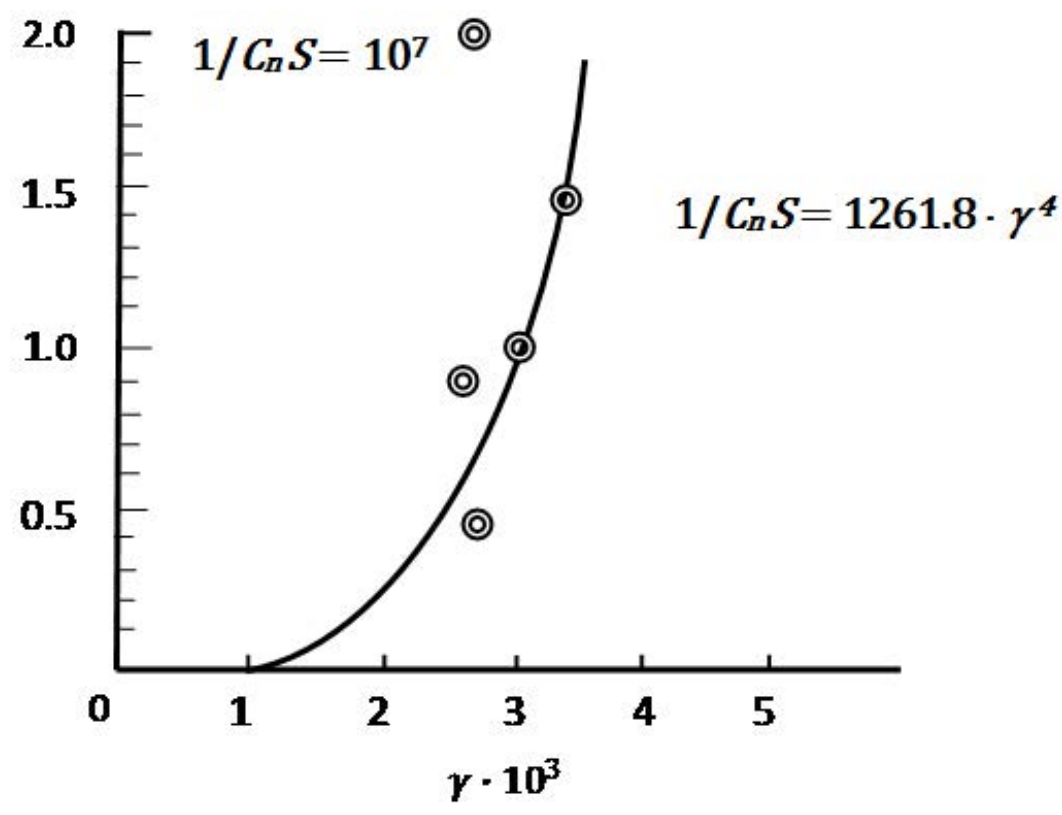

Figure 2: The relation of fire-extinguishing capacity and recombination, coefficient of atomic oxygen.

The growth of $\gamma_{0}$ rapidly increases the fire-extinguishing ability. A positive correlation between them is indicates the priority of heterogeneous mechanism in fire-extinguish action of powders, while existing deviations are associated with homogeneous action of gases on flame because of particles destruction.

For example, $\gamma_{0}$ value for perlites $\left(2.6 \cdot 10^{-3}\right)$ is close to zeolites $\left(2.7 \cdot 10^{-3}\right)$, while perlites fire-extinguishing ability $\left(0.20 \cdot 10^{-6}\right)$ exceeds that of zeolites $\left(0.045 \cdot 10^{-6}\right)$, which, in our opinion, is caused by the fact that perlites at high temperature are characterized by blowingup of particles and additional homogeneous effect of powder fine particles on flame. At the same time, significant deviation is evidently seen in case of clay shales. Particularly high value of $\gamma_{0}$, which 2.0-2.5 times exceeds the values of recombination coefficient of zeolites and perlites is corresponded with low value of fire-extinguishing capacity. This is basically caused by the high specific weight, high dispersion and specific surface area of clay shales, which results in the increase of powder mass consumption and surface concentration. Hence, recombination coefficient of composite powder received with introduction of clay shales in zeolites and perlites considerably increases, while fire-extinguishing capacity $\left(1 / C_{n} \cdot S\right)$ changes insignificantly.

From the all above-mentioned we can suggest, that composite fire-extinguishing powders based on zeolites, perlites and clay shales are characterized by the high homogeneous as well as a heterogeneous inhibition of combustion process and thus they are characterized by high fire- extinguishing effect. At the same time, it should be noted, that the efficiency of the received powders is not worse than of standard powders of common production, but unlike them they are halogen-free, environmentally safe and inexpensive (1.2-2 times cheaper). 


\section{CONCLUSIONS}

- The newly developed fire-extinguishing powders will be produced by mechanical treatment and mixing of local mineral raw materials: zeolite, clay shale and perlite, they do not require any additional chemical processing and modification using expensive, halogen containing hydrofobizers. Thus, they are halogen-free, environmentally safe, highly efficient, universal and significantly cheaper (1.2-2 times cheaper) than the imported analogues.

- The technology for production of these powders differs from the common production technologies. It is simple and low-cost.

- The obtained powders are characterized with high performance characteristics, high fire-extinguishing capacity and high values of recombination coefficients of atomic oxygen. Thus, they are characterized both by high homogeneous and heterogeneous inhibition of combustion process.

- The received powders can be effectively used for extinguishing of all class of fires at underground and aboveground areas within a wide temperature range $(-500 \mathrm{C}$ to $+500 \mathrm{C})$ and at low temperatures where $\mathrm{CO}_{2}$, water and Freon cannot be used.

- On the basis of experimental results, it can be stated, that zeolites in composite powders play the role of efficient hydrophobizers, which allows to create a wide range of zeolite-containing fire-extinguishing powders on the basis of local mineral raw materials.

\section{ACKNOWLEDGEMENTS}

The paper was prepared within the framework of the project \#216770 "New type fire-extinguishing powders and foam-suspensions based on local mineral raw materials" funded by the Shota Rustaveli National Science Foundation.

\section{REFERENCES}

[1] Takahashi, F., Linteris, G.T.\& Katta, V.R., Physical and Chemical Aspects of CupBurner Flame Extinguishment. Halon Options Technical Working Conference, 15th Proceedings, Albuquerque, NM, pp. 1-10, 2005.

[2] Baratov, A.N. \& Vogman, L.P., Fire extinguishing powder compositions. Stroyizdat, Moscow, 1982.

[3] Schreiberg, G. \& Porret, P., Fire-extinguishing Means, M., 1985.

[4] Baratov, A.N., Kopylov, N.P. \& Timofeev, E.V., About Substitution for OzoneDepleting Agents for Fire Extinguishing. Proceedings of the 12th Halon Options Technical Working Conference, eds. R.G. Gann \& P.A. Reneke, NIST SP 984: Gaithersburg, MD, pp. 1-12, 2002.

[5] Gurchumelia, L., Bejanov, F., Baliashvili, G. \& Sarjveladze, N., Development of Novel Composite Fire-extinguishing Powders on the Basis of Mineral Raw Materials. Modelling, monitoring and management of Forest Fires. WIT Transactions on Ecology and the Environment, Wit Press: Toledo, Spain, 119, pp. 61-71, 2008.

[6] http://library.witpress.com/pages/PaperInfo.asp?PaperID=19595.

[7] Tsitsishvili, G.V., Andronikashvili, T.G. \& Kirov G.N., Natural zeolites. Prod. "Chemistry", Moscow, 1985.

[8] Gurchumelia, L.V., Bezarashvili, G., Chikhradze, M.N. \& Chudakova O., Investigation of performance properties of novel composite fire-extinguishing 
140 Safety and Security Engineering VII

powders based on mineral raw materials. Materials Characterisation, WIT Transactions on Engineering Sciences, Wit Press: New Forest UK, Vol. 64, pp. 337-347, 2009.

[9] http://library.witpress.com/pages/PaperInfo.asp?PaperID=20159

[10] Fire Extinguishing Powders of General Purpose. Testing methods. Normative Documents, НПБ, Russia, pp. 170-98 1998.

[11] Methodics for Laboratory Work. Abstract, «Fire Extinguishers», Moscow, 2005.

[12] Petviashvili, D., Sulaberidze, K., Bezarashvili, G., Gurchumelia, L. \& Abashidze, G., Investigation of heterogeneous recombination of oxygen atoms on solid surfaces of different composition. Series Chemistry, Tbilisi, 4(35), 2009. 